\title{
Ginsberg's Translations of Apollinaire and Genet in the Development of his Poetics of "Open Secrecy"
}

Véronique Lane
Lancaster University

Follow this and additional works at: https://docs.lib.purdue.edu/clcweb

Part of the American Literature Commons, French and Francophone Literature Commons, and the Translation Studies Commons

Dedicated to the dissemination of scholarly and professional information, Purdue University Press selects, develops, and distributes quality resources in several key subject areas for which its parent university is famous, including business, technology, health, veterinary medicine, and other selected disciplines in the humanities and sciences.

CLCWeb: Comparative Literature and Culture, the peer-reviewed, full-text, and open-access learned journal in the humanities and social sciences, publishes new scholarship following tenets of the discipline of comparative literature and the field of cultural studies designated as "comparative cultural studies." Publications in the journal are indexed in the Annual Bibliography of English Language and Literature (Chadwyck-Healey), the Arts and Humanities Citation Index (Thomson Reuters ISI), the Humanities Index (Wilson), Humanities International Complete (EBSCO), the International Bibliography of the Modern Language Association of America, and Scopus (Elsevier). The journal is affiliated with the Purdue University Press monograph series of Books in Comparative Cultural Studies. Contact: <clcweb@purdue.edu>

\section{Recommended Citation}

Lane, Véronique. "Ginsberg's Translations of Apollinaire and Genet in the Development of his Poetics of "Open Secrecy"." CLCWeb: Comparative Literature and Culture 18.5 (2016): <https://doi.org/10.7771/1481-4374.2976>

This text has been double-blind peer reviewed by $2+1$ experts in the field.

The above text, published by Purdue University Press @Purdue University, has been downloaded 175 times as of $11 /$ $07 / 19$.

This document has been made available through Purdue e-Pubs, a service of the Purdue University Libraries. Please contact epubs@purdue.edu for additional information.

This is an Open Access journal. This means that it uses a funding model that does not charge readers or their institutions for access. Readers may freely read, download, copy, distribute, print, search, or link to the full texts of articles. This journal is covered under the CC BY-NC-ND license. 


\title{
PURDUE
}

\author{
UNIVERSITY PRESS <http://www.thepress. purdue.edu>
}

\section{CLCWeb: Comparative Literature and Culture}

ISSN 1481-4374 <http://docs.lib.purdue.edu/clcweb> Purdue University Press @Purdue University

CLCWeb: Comparative Literature and Culture, the peer-reviewed, full-text, and open-access learned journal in the humanities and social sciences, publishes new scholarship following tenets of the discipline of comparative literature and the field of cultural studies designated as "comparative cultural studies." In addition to the publication of articles, the journal publishes review articles of scholarly books and publishes research material in its Library Series. Publications in the journal are indexed in the Annual Bibliography of English Language and Literature (Chadwyck-Healey), the Arts and Humanities Citation Index (Thomson Reuters ISI), the Humanities Index (Wilson), Humanities International Complete (EBSCO), the International Bibliography of the Modern Language Association of America, and Scopus (Elsevier). The journal is affiliated with the Purdue University Press monograph series of Books in Comparative Cultural Studies. Contact: <clcweb@purdue.edu>

\section{Volume 18 Issue 5 (December 2016) Article 6 \\ Véronique Lane, \\ "Ginsberg's Translations of Apollinaire and Genet in the \\ Development of his Poetics of 'Open Secrecy'" \\ <http://docs.lib.purdue.edu/clcweb/vol18/iss5/6>}

Contents of CLCWeb: Comparative Literature and Culture 18.5 (2016)

Special Issue Global Beat Studies. Ed. Oliver Harris and Polina Mackay

<http://docs.lib.purdue.edu/clcweb/vol18/iss5/>

Abstract: In her article "Ginsberg's Translations of Apollinaire and Genet in the Development of his Poetics of 'Open Secrecy'" Véronique Lane analyzes the extent to which the journals, letters and poems of Allen Ginsberg are marked by constant reference to literary models that give just as much weight to French as to American writers. Focusing on his long involvement with Guillaume Apollinaire and Jean Genet's works, Lane argues that Ginsberg meticulously constructed the genealogy of his poetry through a threefold strategy of literary quotation, translation and encryption. Uncovering this strategy through analysis of "Howl," "At Apollinaire's Grave," and "Death to Van Gogh's Ear!" does more than simply nuance or deepen our understanding of Ginsberg's work in the 1950s; it reveals that it was largely through his engagement with French literature that he developed the very aesthetic and hermeneutic method of his poetry. 


\section{Véronique Lane}

\section{Ginsberg's Translations of Apollinaire and Genet in the Development of his Poetics of 'Open Secrecy'}

The variorum edition celebrating the thirtieth anniversary of Allen Ginsberg's most famous poem makes plain a central but very little explored dimension of its genesis. From Ginsberg's extensive lineby-line annotations of "Howl" to the inclusion of works by Antonin Artaud and Guillaume Apollinaire in an appendix section of "model texts," the edition documents the crucial role that French literature played in the poem's genetic history. And yet, the French background to not only "Howl" but to much of Ginsberg's production in the 1950s continues to be overlooked. If the reception of his poetry has consistently entailed retelling the same national narratives at the expense of others, there are obvious reasons for it, ranging from the Americanist expertise of his critics to the overwhelming identification of "Howl" with the influence of Walt Whitman. Ginsberg himself twice declared Whitman "a mountain too vast to be seen" (Howl 155, 176), and this mountain has loomed so large over his most celebrated poem that, since its publication in 1956, it has indeed been very difficult to see anything else.

The titles of the two major critical volumes dedicated to "Howl," Jonah Raskin's study American Scream: Allen Ginsberg's "Howl" and the Making of the Beat Generation (2004) and Jason Shinder's anniversary collection, The Poem That Changed America: "Howl" Fifty Years Later (2006), sum up the emphatically US-American historical context in which "Howl" has almost exclusively been read. Leaving aside the youthful "New Vision" phase focused on Rimbaud that Ginsberg shared with Burroughs and Kerouac in New York during the 1940s, the logical place to look for his relationship with French literature has always been those poems written after "Howl" and in France, a context that could only prompt biographical readings. After moving there in Fall 1957, Ginsberg did write several important poems in Paris, two of whose titles associated him with French poets: "At Apollinaire's Grave" and "Death to Van Gogh's Ear!" (which evokes Artaud's infamous text "Van Gogh the Man Suicided by Society"). However, it would be a fundamental error to chiefly associate either poem with the geographic and cultural location of their writing. And so, it is necessary to contest the argument of the only critic to have made a sustained reading of "At Apollinaire's Grave," Richard Swope, who takes the poem as evidence of Ginsberg's engagement with "literary Paris" (Swope 188). Setting out to redress the striking lack of "detailed explication" of "At Apollinaire's Grave," Swope insists on the importance to Ginsberg's composition of his actually being in Paris. While plausible, the argument conceals more than it reveals by slighting the vital impact of Ginsberg's engagement with French poetry on his preParis work, including "Howl." For if we compare two of his major statements about the aesthetic genealogy of "Howl"-his letters to Richard Eberhart in 1956 and to John Hollander in 1958-they show no shift of balance in Ginsberg's references between American and French poets: the stress on French poetry appears just as strongly before as after his year in Paris (Howl 151-54, 162-64).

Rather than understanding "At Apollinaire's Grave" as a symbol of Ginsberg's relationship with French literature, because it demonstrated what he "produced during and from his experience in Paris" in 1958 (Swope 188), we should look for a more subtle logic at work in it, one that the American poet himself acknowledged three decades later. Asked about the significance of Apollinaire for him, in 1989 Ginsberg replied: "Yes, when I lived in Paris I wrote an homage at his tomb. And it was supposed to be a signal to the American academics where I was coming from, but I don't think they picked up on it" (Ginsberg, Spontaneous Mind 504). This remark registers how acutely Ginsberg felt at the time "Howl" appeared, in 1956, that he was not being taken seriously-"Everybody's serious but me", as he bluntly put it in "America," a poem he began while still at work on "Howl" (Collected Poems 147)-and reveals that in aesthetic terms, to be taken seriously for him implied being recognized as a poet working within French as well as American traditions. We might add that academics still misunderstand Ginsberg's poetry for they haven't picked up on his "signal," continuing either to neglect or misread the importance for "Howl" of those French poets long hidden in the shadow of Whitman.

Thirty years after the variorum edition of "Howl"-a publication which in so many ways documented the dual traditions informing Ginsberg's great poem-this article reassesses the place of French literature in his breakthrough as a poet. More specifically, by following the trail hinted at by multiple references to Apollinaire and Genet from the 1950s onwards, it reveals the ways in which Ginsberg constructed the genealogy of his poetry through a threefold strategy of quotation, translation and encryption. Uncovering Ginsberg's strategy through analysis of "At Apollinaire's Grave" and "Death to Van Gogh's Ear!" does more than simply nuance our understanding of "Howl" by revealing that it was already at work two years before going to Paris; it makes clear that it was largely through his engage- 
ment with French literature that the American poet developed the very aesthetic and hermeneutic method of his poetry.

Let us begin with the poem Ginsberg hailed as "a signal," whose very title calls for a biographical reading: "At Apollinaire's Grave." To take it seriously means going beyond the narrative that begins with its first lines' factual statements of location and purpose: "I visited Père Lachaise to look for the remains of Apollinaire / the day the U.S. President appeared in France for the grand conference of heads of state / so let it be the airport at blue Orly a springtime clarity in the air over Paris / Eisenhower winging in from his American graveyard" (Collected Poems 180). It also requires us to go beyond the political reading suggested by the parallel drawn between Ginsberg's visit to the Paris cemetery and Eisenhower's arrival at Orly airport. For while the US President's coming to Paris for the first summit meeting of NATO was indeed politically significant, the poet's planes and airports are also allusions to the aerial vision of Apollinaire's own "Zone" four decades earlier: "The airplane lands at last without folding its wings" ("Zone" reprinted in Howl 180). Likewise, while Ginsberg's later attention to "that fantastic cranial bandage" points to Apollinaire's head wound from the First World War and, as he notes, "the West is at war again," the poem does not maintain such political rhetoric. Rather, it uses the presence of the poet at a site that marks another poet's absence to construct a hermeneutic procedure based on degrees of presence and absence, on what can be recognized and what remains encrypted, there but hidden in plain sight.

"At Apollinaire's Grave" starts by describing Ginsberg's walk through the cemetery with Peter Orlovsky, looking "for the lost address of a notable Frenchman of the Void" to pay their "tender crime of homage to his helpless menhir" (Collected Poems 180). The "crime" in question is not political but literary, as Ginsberg insists in the ironic action at the centre of the poem's first part: "and lay my temporary American Howl on top of his silent Calligramme / for him to read between the lines with Xray eyes of Poet / as he by miracle had read his own death lyric in the Seine / I hope some wild kidmonk lays his pamphlet on my grave for God to read me on cold winter nights in heaven" (180).

This passage is multi-layered and carefully judged tonally. Ginsberg offers his "Howl" as "temporary"-of its moment in time, not yet in eternity like Apollinaire's Calligrammes-while by opposing "American" to "silent," he admits to a noisy vulgarity in "Howl." There is a definite element of Ginsberg's typical self-mockery here: what nerve, to fantasize at Apollinaire's graveside future acts of homage paid to himself. Such a rudimentary reading misses, however, that the poet combines being loud and open with being silent and subtle, and that beyond the homage brashly announced in the poem's title, there lies a formal affiliation that works through the quietest of hints.

To recognize Ginsberg's hints or "signals" within "At Apollinaire's Grave," we have to re-read the opening of the poem, that is to say the epigraph that comes between the poem's title and its very first line. Before Ginsberg makes his search for Apollinaire's physical remains, a search that can only be biographical, he gives us what will always "remain" of the poet, his actual words: "voici le temps / Où I'on connaîtra l'avenir / Sans mourir de connaissance" (Collected Poems 180). Even readers untutored in French would identify these words as those of Apollinaire, given the very title of Ginsberg's homage; but why not name their source? Visibly quoting from and yet failing to indicate the provenance of these lines as Apollinaire's "Les collines" ("The Hills"), at the very outset of his poem Ginsberg addresses the aesthetic and hermeneutic issue of naming names, of when to do it and when not. An attentive reader of his oeuvre quickly grasps that Ginsberg was "a name-dropper on an epic scale," who saw in this practice a way to intensify his relationship with readers by enticing them to follow his path, "investigate his names, ingest his tradition" (Muckle 10, 30). However, I would argue that Ginsberg mastered enigmatic omissions-ellipses, elisions-as well as loud enumerations for the exact same reason: withholding key information arouses curiosity perhaps even more than divulging it and is Ginsberg's unrecognized strategy to draw in the closest readers. In its explicit naming of literary heroes, "At Apollinaire's Grave" strongly resembles "Death to Van Gogh's Ear!", giving us not only Apollinaire, but also Artaud, Jacob, Picasso, Rousseau, Tzara, Breton, Cendrars, Vaché, Cocteau, Rigaut and Gide ("Death to Van Gogh's Ear!" likewise gives us Artaud, Genet, Lorca, Crane, Whitman, Mayakovsky, Lindsay, Blok, Pound and Poe). Such long lists draw attention to themselves as well as to the poetic lineage Ginsberg desired for his poetry. But the most significant gesture weaving "Death to Van Gogh's Ear!" into the French tradition was again as subtle as subtle can be, and has passed unnoticed. In "Death to Van Gogh's Ear!," Ginsberg quotes the very same verse from "Les collines" that forms the epigraph of "At Apollinaire's Grave," but this time in English: "Now is the time for prophecy without death as a consequence" (Collected Poems 168).

The first draft of "At Apollinaire's Grave" figures in Ginsberg's journals under the heading "Now time for Prophecy," and editor Gordon Ball's footnote rightly notices the return of Apollinaire's verse in "Death to Van Gogh's Ear!" but overlooks the originality of the recurrent quotation (Journals 404). 
That is to say, we would naturally assume that Ginsberg quoted Apollinaire in translation, but in fact, no translation of "Les collines" was available at the time Ginsberg composed "Death to Van Gogh's Ear!" and "At Apollinaire's Grave," between November 1957 and Spring 1958. The first translation of Apollinaire's Calligrammes by Roger Shattuck was not printed until 1971; "Death to Van Gogh's Ear!" was written and indeed published in Kaddish and Other Poems more than a decade earlier: its composition therefore implied an unprecedented act of translation, and a very interesting one.

Comparing Ginsberg's translation to Shattuck's clarifies both the nature and the depth of the poet's relationship to Apollinaire's works. Shattuck translates "voici le temps / Où l'on connaîtra l'avenir / Sans mourir de sa connaissance" by "The time is here / In which the future can be known / Without death as a consequence" (Selected Writings 147). This translation has five words where Ginsberg had a single one, a word so fundamental to his poetry that it would in fact become a landmark of its criticism: "prophecy." In Ginsberg's translation, "prophecy" boldly replaces the impersonal pronoun "on" in "où I'on connaîtra l'avenir" and becomes the heart of the verse: "Now is the time for prophecy without death as a consequence" (Collected Poems 168). Not only is "prophecy" central under Ginsberg's pen, it also clearly stands for "poetry." In light of the trial "Howl" was undergoing at the time Ginsberg translated Apollinaire's verse in "Death to Van Gogh's Ear!", the line can logically be interpreted as "Now is the time for poetry without death as consequence," "death" standing for the cumulative effect on the poet of censorship and social exclusion. Does Ginsberg's audacious translation drag Apollinaire too far into his own territory? Or does it quite simply reflect the result of his finding himself so much at home in Apollinaire's universe that he felt he had the necessary authority to re-create-rather than literally translate-his poetry? I would argue for the latter. Ginsberg's bold insertion of "prophecy" inviting its equation with "poetry" is not far removed from Apollinaire's own vision of the poet and his faculties, for "Les collines" does portray poets as prophets: "Certain men stand out like hills / Rising above their fellow men / To see the future from afar / Better than they see today / Clearer than if it were the past" (Selected Writings of Guillaume Apollinaire 145).

It was an ambitious solution on Ginsberg's part to condense what Apollinaire expressed in six words ("où I'on connaîtra l'avenir") into a single one ("prophecy"), but we should admire his economical translation that turns three lines into two perfect octameters. In comparison, Shattuck's passive structure heavy with prepositions ("in which the future can be known") stands closer to the original line, but is far less elegant. Ginsberg's version is the distinctive work of a writer-translator. Every good translation of course includes the "becoming-writer" of its translator, but his or her name nevertheless remains in the shadow of the authors' name. Ginsberg's translation is doubly transgressive in this sense: not only is it relatively "unfaithful" to the original verse, it also furtively silences its author's name. The epigraph of "At Apollinaire's Grave" didn't identify Apollinaire as its author, but its predominant position (outside the text) and its foreign language (French) guaranteed that readers wouldn't take Ginsberg as its author either. In "Death to Van Gogh's Ear!" Ginsberg's relationship to French literature deepens as he goes one step further: from quoting Apollinaire's words to translating them without acknowledging their source. In short, the "tender crime of homage" evoked in "At Apollinaire's Grave," Ginsberg's translation in "Death to Van Gogh's Ear!" materialized.

Primed by knowledge of the importance of Apollinaire's "Les collines" and by Ginsberg's repeated quotations of the poem's passage dealing with death and prophecy, from "At Apollinaire's Grave" to "Death to Van Gogh's Ear!," we can finally identify in "Europe! Europe!" written a few months later a remarkably condensed series of allusions: "Apollonic radiance in hillsides / littered with empty tombs" (Collected Poems 173). Here we have encryptions of the poet's name ("Apollonic") and of his poem "The Hills" ("hillsides"), as well as of Ginsberg's graveyard "search" in Père Lachaise ("empty tombs"). The extreme density and obliqueness of these three allusions echo the imagistic method Ginsberg had developed in "Howl" and, crucially, here implies his method's specific affinity with the French poet. Recognizing Ginsberg's use of Apollinaire's verse from "Les Collines" both in French and English allows us to confirm its importance for him, while it also stresses how, thirty years before the variorum edition of "Howl," the poet was already trying to inscribe his works in a nexus of textual allusions formally relating it to Apollinaire's. The point, then, is not simply the recurrence of allusions to Apollinaire across several poems composed in Paris during the late fifties, but that Ginsberg manifestly meant them as a trail of clues or "signals" to be deciphered. To borrow a phrase he would later apply to "Howl," from quoting to translating Apollinaire, Ginsberg developed a multi-layered hermeneutic strategy of "open secrecy" ("Notes" 80).

Ginsberg's strategy of revelation and concealment is generally seen in relation to personal biography: a "knowing" reader can decipher the private allusions behind the text, especially behind "Howl" and its references to the "best minds" of his generation. However, his stealthy quoting and translating of "Les collines" across three poems reveals that the tension between what is clear and what is oblique 
under Ginsberg's pen also applies to literary allusions. If the famous reference to "N.C. secret hero of these poems" in "Howl" divides readers "into the initiated and the uninitiated" (Yu 25), I would argue that the same goes aesthetically: that "Howl" encodes formal secrets, which have been overlooked and which also produce insiders and outsiders.

In the variorum edition of the poem, Ginsberg claims that the versification of "Howl" specifically embraces Apollinaire's innovative aesthetics: "Apollinaire introduces the jump cut ... montage of time \& space, surrealist juxtaposition of opposites, compression of images, mind gaps or dissociations, 'hydrogen jukeboxes'" (Howl 175). Ginsberg's remark here glosses the lines of "Howl" that spell out the poem's aesthetic technique ("who made incarnate gaps in Time \& Space through images juxtaposed") and the exemplary image from the poem he never tired of repeating ("hydrogen jukebox"), and crucially attributes both of them to Apollinaire (Howl 6, 3). The inference that the poetics and trademark image of Ginsberg's most famous poem derive from the French poet is so startling that we have to wonder why it has been overlooked. What has been missed here is the link between Apollinaire's aesthetic technique and its representation in "Howl." As the drafts reprinted in the variorum edition reveal, Ginsberg's very desire to name names within "Howl," to clarify its relationship to the work of Apollinaire and so guide its reception, had to be revised because it contradicted what was essential to the very aesthetic the two poets shared: "the ellipsis catalog" (6). When Ginsberg annotates this phrase in the variorum edition of "Howl," he significantly illustrates it with the image he associated with Apollinaire: "This stanza concerns itself with aesthetic technique, the mechanisms of surrealist or ideogrammatic method, the juxtaposition of disparate images to create a gap of understanding which the mind fills in with a flash of recognition of the unstated relationship (as 'hydrogen jukebox')" (130). To create "a gap of understanding" and let the reader work out the association, it was necessary for the poet to leave his essential relationship to Apollinaire's practice "unstated" in "Howl" and to keep it oblique in the variorum edition.

As the poem's genetic history shows, the process of encryption and the question of audience were already crucial to how, in fall 1955, Ginsberg wrote and indeed re-wrote "Howl." Of the many revisions he made to his poem, the most striking is the redaction of a long reading list in the form of a catalog of names. In retrospect, this deleted list seems like a trial run for the rosters of names that appear in "At Apollinaire's Grave" and "Death to Van Gogh's Ear!" If we set aside Buddha and those in Ginsberg's circle (Kerouac, Burroughs, Cassady and Carr), we are left with eleven writers of whom two are American (Wolfe, Whitman), four are European (Marx, Spengler, Gurdjieff, Dostoyevsky), and five specifically French (Artaud, Genet, Rimbaud, Céline and Proust) (Howl 22-23). This passage is both the longest section of deleted material in Ginsberg's first draft and the most eye-catching from the point of view of the poem's genealogical identity. And yet, Ginsberg annotates it with a tone that is curiously disparaging as well as laconic: "Next drafts eliminate this ponderous lineage" (Howl 136). Since the variorum edition sets out to name names, to resurrect and expand upon the very lineage Ginsberg cut from the poem itself, there is an odd contradiction here: to dismiss his original lines as too awkwardly weighty in the context of a book that, in sharp contrast to the original little Pocket Poet edition, is literally "ponderous" (weighing over two pounds). Uncovering Ginsberg's strategy of concealment enlightens this paradox. The "weight" or the significance of "Howl" was to be conveyed by powerful images ("hydrogen jukebox") standing in for redacted names (Apollinaire): by an "ellipsis catalog," indeed (Howl 6).

One such redaction to "Howl" involved not the name but the very words of Jean Genet. Like "Death to Van Gogh's Ear!," the first draft of "Howl" not only quoted but also translated a French line: "who didn't have time to speak among themselves of love" ("Nous n'avions pas fini de nous parler d'amour") (Howl 23; Genet 215). Few if any contemporary readers would have recognized this line's provenance as the long poem that Genet composed in prison to honor his friend Maurice Pilorge sentenced to death, since "Le Condamné à mort" (Man in Death Cell in Ginsberg's version) had not yet been translated into English. Another long poem by Genet, "Un Chant d'Amour" ("A Love Song"), had been translated in The Window in 1954, and Ginsberg might have had access to it before composing "Howl" in 1955, but there would be no translation of "Le Condamné à mort" until City Lights published its first thirty-three quatrains in 1960 (Genet, Men Under Death Sentence, translated by Lola Pozo). Ginsberg's involvement with "Le Condamné à mort" rivals his treatment of "Les collines" by Apollinaire as it goes back three years before he started composing "Howl." "I am translating a poem called 'Le Condamné à mort' ('Man in Death cell')," he told Kerouac as early as in February 1952, before giving him no fewer than six lines of the formidable task he had set himself (Ginsberg Kerouac Letters 141). His translation of Genet's stanza in 1952 was just as audacious as his translation of Apollinaire's line would be in 1957: Genet's "Gamin d'or sois plutôt princesse d'une tour," for instance, implies a classic passive comparison ("plutôt" / "rather") that Ginsberg's "Golden boy, go be a Princess in a tower," 
brilliantly transforms into an active poetic projection ("go be"). Considering the sophisticated vocabulary and thorny syntax of Genet's "Le Condamné à mort," let alone its length-264 lines, or "65 huge Dakar Doldrums" as Ginsberg put it to Kerouac-we shouldn't take the amount of time and energy necessary to such a translation lightly (Letters 141). In fact, we have every reason to believe that Ginsberg was still translating Genet's long poem three years later when he began to compose "Howl," since in mid-August 1955 he wrote to the same correspondent he was now having help translating "Genet poetry," certainly meaning "Le Condammé à mort," from his neighbor, "Guy Wernham the translator of Lautréamont" (Letters 317).

In the 1950s, Modern French literature for New Yorkers was almost exclusively to be found in little magazines, whose editors privileged short stories and poems for obvious reasons of format. In that context, the translators played a crucial role, and critics who could read but not quite write in French also had to improvise themselves as translators, if only to give a taste of the texts they were asked to review. Such was apparently the case for the reviewer of Genet's novel Miracle de la Rose in Partisan Review, who translated Genet's first excerpt Ginsberg commented on, in 1949: "I read a 3 page excerpt on the mysteries of shoplifting ending (as I remember) 'and so it is that at the judgement of the apocalypse God will call me to the dolmen realms with my own tender voice, crying, 'Jean, Hean.' (Dolmen realms is my own phrase)" (Ginsberg Kerouac Letters 104). In this letter to Kerouac, Ginsberg's parentheses are highly significant. The first parenthesis, "(as I remember)," reveals an extremely complex act of appropriation: a translation-from memory-of a translation-of Genet's novel, which is contradicted by the second parenthesis, "(Dolmen realms is my own phrase)." For how could Ginsberg be certain that "dolmen realms" was his "own phrase" if he wrote the excerpt relying on a vague memory ("as I remember")? If only out of pride, would he not have double-checked the version given in the Partisan article to be sure that this was indeed his own translation? Certainly, the need to insist that "dolmen realms" are his words sets the tone and intensity of Ginsberg's relationship to Genet: the poet is so struck by Genet's style that he cannot resist stealing the translator's place and inventing phrases of his own.

Ginsberg pushed his involvement with Genet's works even further by thus turning translation into creation. "Howl" may no longer feature his draft line translating "Le Condamné à mort"-_"who didn't have time to speak among themselves of love" (Howl 23)-but Ginsberg's famous poem still bears the mark of his even earlier translation of Genet's Miracle de la Rose: "rocking and rolling in the midnight solitude-bench dolmen-realms of love" (6). "Dolmen-realms" here has an interesting status, for it is neither a quotation nor a translation per say, but a form of creative adaptation that Andre Lefevere has termed "refraction" (233-49). That the phrase Ginsberg derived from Genet and claimed so insistently as his own in 1949 remains in "Howl" symbolizes his intense engagement with Genet before as well as while composing "Howl." It also suggests that Genet's oeuvre played a very similar role to Apollinaire's in the development of his poetics. And yet, its provenance and significance are allowed to pass without notice, both in the poem and in the variorum edition thirty years later.

The drafts of "Howl" show how conflicted Ginsberg had, in fact, always been about communicating the poem's genealogy. His ambivalence is captured not only by lines such as the "ponderous lineage" or the translation of Genet's Le Condamné à mort he cut in revision, but also by images such as "hydrogen jukebox" and "dolmen-realms" that would remain in the text. One of them, which seems to serve as a mise-en-abîme of the poem, is "leaving a trail of ambiguous postcards" (Howl 3). Significantly, this phrasing was itself the revision of a first draft line that referred to "posting cryptic picture postcards" (Howl 13). Ginsberg's trail of revisions, shifting from the hermetic secrecy of encryption to the teasing equivocation of ambiguity, shows that "Howl" wrestled with the hermeneutical problem that "At Apollinaire's Grave" and "Death to Van Gogh's Ear!" would continue to address: was it better to be cryptically closed or ambiguously open?

The answer Ginsberg arrived at seems to be that it was better to say as little as possible, which is why for the variorum edition of "Howl" he probably needed to say so much. He had to spell out what was missing from or hidden in "Howl" because so few readers, especially so few "American academics" to recall his 1989 interview, had recognized its formal affiliations with European literature, above all with French Modernist poetry. Appropriately enough, Ginsberg's strategy of hinting is itself only hinted at in the variorum edition of his famous poem, but there is compelling contemporary evidence that this ambivalent approach to communication was in the poet's mind in the months leading up to the composition of his famous poem. In early 1955, Ginsberg had been encouraged by Kerouac to follow his own enthusiastic embrace of Buddhist teaching and, returning from the library in San Francisco with an armful of texts, he quickly connected them to the key aesthetic and philosophical issues that would inform the writing of "Howl," above all how to achieve the "breakthrough of eternity into time": "I begin with a basic X which is 'unspeakable,' 'unknowable' and 'unthinkable.' Believe this X can how- 
ever be experienced. I image [sic] it can also be communicated, or hinted at, pointed to (with finger, image, X, poem, word, etc.) (letter too). Communications on the subject are limited" (Ginsberg, Kerouac Letters 263). As already demonstrated, even "At Apollinaire's Grave," which seems to shout its genealogy from the rooftops, holds back such an "X." Although its "open secrecy" appears to be located in the poem's epigraph-citing lines from the unnamed poem of Apollinaire-it is not so much what Ginsberg quotes as the words missing from "Les Collines" that matter, which are represented by the enigma of an unnecessary ellipsis: ". . . voici le temps."

The significance of this ellipsis is double. First, and most naturally, it is a question of content: what does the ellipsis omit? The missing phrase turns out to be the nostalgic refrain of "Les Collines": "Jeunesse adieu." Ginsberg's elision of these words certainly registers his own anxiety at the loss of youth, a mortifying subject that seems to support readings such as Tony Trigilio's, which sees him as "trapped in a graveyard" and his poem as therefore a dead-end: "the speaker of 'At Apollinaire's Grave' never leaves the Père Lachaise Cemetery itself. . . never leaves the place of the dead" (Trigilio 210). But the finality of the last line from "At Apollinaire's Grave"-"I am buried here and sit by my grave beneath a tree" (Collected Poems 182)-is more apparent than real, or at least more complicated. For it doubles the poem's narrator, implicitly into a body that lies in the grave and the self or soul that sits nearby under a symbol of life, "beneath a tree." "At Apollinaire's Grave" also transcends the inevitable closure of death by projecting its author beyond the cemetery and writing a "future poem": "[I] will walk down the streets of New York in the black cloak of French poetry / improvising our conversation in Paris at Père Lachaise / and the future poem that takes its inspiration from the light bleeding into your grave" (Collected Poems 181).

Following Apollinaire's own innovative practice of spatial projection-which Ginsberg would later coin "jump cut" (Howl 175)-the US-American in Paris can imaginatively switch places, finding himself back in New York dressed as a French poet. This switch mirrors the surprising Anglicization of Guillaume Apollinaire, whom Ginsberg initially addresses as "William," and the "envy" he claims feeling for his fame and "accomplishment for American letters" (Collected Poems 180). The image of the "cloak" is dramatic, melodramatic even, and that it is "black" might suggest death, but it also combines the opaque with that which is made explicit (his debt to Apollinaire and French Poetry), and so implies disguise, anonymity. In short, it illustrates the very concealment that is the poem's strategy. Clearly, the question of naming names, of how explicit Ginsberg needed to be about identifying his poetic genealogy, had also been a key issue in "Howl," and the difference between the implicit and explicit strategies of the two poems in fact suggests that Ginsberg wrote "At Apollinaire's Grave" looking back at "Howl" with some regret, perhaps thinking he had veiled himself too well in that "black cloak of French poetry." This regret is hinted at in the extraordinary line that identifies Apollinaire as his own ideal reader: when Ginsberg lays a copy of "Howl" on the Frenchman's grave, it is "for him to read between the lines with Xray eyes of Poet" (Collected Poems 180). But since Apollinaire is dead and cannot fulfill Ginsberg's wish to be "read between the lines," who is the poem really addressing here, if not us, unknown yet ideal readers of today?

This line reveals the most cryptic manner in which "At Apollinaire's Grave" operates as a homage and demonstrates how subtly Ginsberg contrived its hermeneutic procedure. The phrase "read between the lines" requires an acute "Xray" reading, which looks for meaning not where we expect it (in the words printed on the page) but in their "negativity" (in the gaps and spaces between them). Such spaces are artificially introduced by Ginsberg through the ellipsis he inserted in place of Apollinaire's own words in the poem's epigraph, but the significance of these three dots is more than a matter of missing content. For they also invite a strictly formal poetic interpretation that demands technical awareness and knowledge. That is to say, we can only grasp how telling this ellipsis is if we notice the otherwise total absence of punctuation marks in Ginsberg's poem-not a comma or a period-and identify this absence as the purest form of homage to Apollinaire, famous as a Modernist poet for his own refusal of punctuation. Inserting the ellipsis in the poem's epigraph was the most secret sign of Ginsberg's "tender homage." But how exactly was it also a "crime" (Collected Poems 180)?

There is perhaps no better way to understand a literary crime than to repeat it: take Apollinaire out of the line from the poem referring to "Howl" and you get the true nature and dedicatee of Ginsberg's wish: "read between the lines." Rather than a fantasy to honor Apollinaire, Ginsberg's poem is an imperative destined to us: this is the true crime perpetrated in "At Apollinaire's Grave." By partly quoting Apollinaire and retrospectively identifying him as the ideal reader of "Howl," Ginsberg did more than inscribe his poetry in a French Modernist tradition (for if that was a crime, it wouldn't be very original and most writers would be criminals); he used Apollinaire's very name, words, and tomb, to win over a new readership. If one of the aims of adding an ellipsis to his epigraph was indeed to honor Apollinaire, another was to re-launch his own image as a poet, to "signal" himself as an author preoccupied 
with hermeneutics, and to present his poetry as full of secrets to decipher. Furthermore, like "Death to Van Gogh's Ear!" and "Europe! Europe!," "At Apolinaire's Grave" challenges our way of reading. In these poems, Ginsberg constantly prompts us to work out what names, what filiations lie behind his creative catalogs and juxtapositions, so that we can at last truly read or experience "Howl": envision Apollinaire behind "hydrogen jukebox" or Genet behind "dolmen-realms." Ginsberg's furtive quotations and translations of Apollinaire and Genet in the 1950s hence reveal within the democratic author of all the exigent poet of a happy few, those who can read across languages and, "with Xray eyes of poets," see what literary genealogy lies behind "compression of images, mind gaps or dissociations" or even behind an ellipsis ... (Collected Poems 180; Howl 175).

\section{Works Cited}

Apollinaire, Guillaume. Calligrammes. Paris: Gallimard, 1966.

Apollinaire, Guillaume. Selected Writings of Guillaume Apollinaire. Trans. Roger Shattuck. New York: New Directions, 1971.

Genet, Jean. Le Condamné à mort. Oeuvres Complètes, Vol 2. Paris: Gallimard, 1951.

Genet, Jean. Men Under Death Sentence. Trans. Lola Pozo. San Francisco: City Lights, 1960.

Ginsberg, Allen. Collected Poems, 1947-1980. New York: Viking, 1985.

Ginsberg, Allen. Howl, Original Draft Facsimile, Transcript and Variant Versions. Ed. Barry Miles. New York: Harper and Row, 1986.

Ginsberg, Allen. "Notes Written on Finally Recording 'Howl'." On the Poetry of Allen Ginsberg. Ed. Lewis Hyde. Ann Arbor: $U$ of Michigan P, 1984.

Ginsberg, Allen. Spontaneous Mind: Selected Interviews, 1958-1996. Ed. David Carter. New York: HarperCollins, 2001.

Ginsberg, Allen. Journals: Mid-Fifties, 1954-1958. Ed. Gordon Ball. New York: HarperCollins, 1995.

Ginsberg, Allen and Jack Kerouac. Jack Kerouac and Allen Ginsberg: The Letters. Ed. Bill Morgan and David Stanford. New York: Viking, 2010.

Lefevere, André. "Mother Courage's Cucumbers: Text, System and Refraction in a Theory of Literature." The Translation Reader. Ed. Lawrence Venuti. London: Routledge, 2001. 233-49.

Muckle, John. "The Names: Allen Ginsberg's Writings." The Beat Generation Writers. Ed. A. Robert Lee. London: Pluto, 1996.

Raskin, Jonah. American Scream: Allen Ginsberg and the Making of the Beat Generation. Berkeley: U of California P, 2004.

Shinder, Jason, ed. The Poem That Changed America: "Howl" Fifty Years Later. New York: Farrar Straus and Giroux, 2006.

Swope, Richard. "Allen Ginsberg and the Beats in Literary Paris, or Apollinaire Through the Door of Ginsberg's Mind." American Writers in Europe, 1850 to the Present. Ed. Ferdâ Asya. New York: Palgrave Macmillan, 2013. 187-206.

Trigilio, Tony. Allen Ginsberg's Buddhist Poetics. Carbondale: Southern Illinois UP, 2007.

Yu, Timothy. Race and the Avant-garde: Experimental and Asian American Poetry Since 1965. Stanford: Stanford UP, 2009.

Author's profile: Véronique Lane teaches French Studies at Lancaster University. Her interests in scholarship include translation studies, comparative literature, French critical thought, as well as nineteenth and twentieth Century French literature and drama. Lane's publications include The French Genealogy of The Beat Generation: Burroughs, Ginsberg and Kerouac's Appropriations of French Literature, from Rimbaud to Michaux (2017).

Email: <veronique.lane@lancaster.ac.uk> 